\title{
高層建物を対象とした可変剛性制震システムの制御特性に関する考察 STUDY ON CONTROL CHARACTERISTICS OF ACTIVE VARIABLE STIFFNESS SYSTEM APPLIED TO A HIGH-RISE BUILDING
}

\author{
高橋 $\overrightarrow{\mathrm{U}}^{*}$, 小堀 鐸二**, 那須 正***, 國末晃寛 ${ }^{* * * *}$ \\ Motoichi TAKAHASHI, Takuji KOBORI, Tadashi NASU \\ and Akihiro KUNISUE
}

\begin{abstract}
This paper describes the control characteristics of the Active Variable System (AVS) system applied to a highrise building. The AVS system controls the structural stiffness to establish non-resonant states against large earthquakes. In practical viewpoints, $10 \%$ damping factor produced by variable stiffness devices is introduced to three selectable stiffness types. The non-resonant control gives smallest responses in uncontrolled three stiffness types, thus producing significant response reduction especially for earthquakes with narrow-range long-period component. The control also reduces input energy of earthquakes, so it realizes effective control with small amount of energy absorption of the variable stiffness devices.
\end{abstract}

\author{
Keywords: Large earthquakes, Semi-active control, Non-resonance, Variable stiffness, \\ High-rise building, Energy input \\ 大地震、セミアクティブ制御、非共振、可変剛性、高層建物、エネルギ入力
}

1.はじめに

地震や強風による建物や構造物の応答を低減するため、各種の構 造制御に関する研究開発が精力的に進められている ${ }^{1), 2), 3) 。 こ れ ら ~}$ のうち、パッシブ制御に属するものには、各種の制震装置により振 動エネルギを吸収し応答低減するタイプや、積層ゴムに代表される 免震装置により振動系の長周期化を図り、1 次共振を避けて（避共 振）応答低減するタイプ 4)な゙がある。また、アクティブあるいは ハイブリッド制御に属するものには、これまではいわゆる付加質量 タイプのものが多く、供給エネルギや制御システムの規模の面から の制約により強風や中小地震を主たる制御の対象外乱としている。

構造制御に対するこのように活発な取り組みは、そもそも小堀に よる制震構造の提唱 うにより本格的に開始された。この提唱におい ては、地震動の正確な予測は将来に渡って困難と言わざるを得ない 状況の中で、今後の建物や都市が求める安全や機能の維持、さらに は社会資本の保全といったより高度な社会的要求に対し、最も確実 に答え得る技術として能動的な制震構造が位置づけられている。そ して大地震を対象とした場合の具体的な実現方法として、構造物の 剛性や減衰といった構造特性を可変とする制御が有効となることが 指摘されている 6。建築や土木構造物のような大型構造物を、大地 震に対して能動的に制御しようとする場合には、付加質量タイプに 代表される制御力による方法では自ずから限界があるためである。 このような観点から提案されたのが可変剛性制御で、これまでにも
幾つかの解析的研究がなされている。すなわち、自律型あるいは予 測型適応制御により可変剛性制御の特性を検討》したものや、瞬間 最適制御に基づいた可変剛性制御則を導いてその制御性能を検討 ${ }^{8)}$ したもの等9がある。

ここで報告する可変剛性制震システム ${ }^{10)}$ (以下、本システム）は、 大地震に対する制御を目的とした非共振型の可変剛性制御を原理と し、この機構を実現する装置として油封式可変剛性装置（以下、装 置）を使用する事を特徵としている。制御の分類上セミアクティブ 制御に属する。セミアクティブ制御は一般的にアクティブ制御に比 ベ制震装置の駆動エネルギが非常に僅かで済み、システム構成も比 較的単純にできる実用上の長所がある上、パッシブ制御に比べ優れ た制御効果が得られるため、近年では大地震対応の制震システムと して活発な研究 11) 15)等がなされている。非共振型の可変剛性制御 は、構造物の剛性を能動的に変化させ時々刻々地震動に対する非共 振化を図って入力を減らし応答低減を目指すところに、従来の多く の制震システムと異なる大きな特徵がある。

本システムに関してはこれまで、小電力で構造物の剛性を高速に

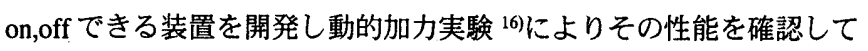
いる。また、模型試験体による振動台実験 ${ }^{10)}$ を通してシステムの成 立性、有効性を検討し、本システムがとりわけ狭帯域の地動に対し て構造物の共振を抑制する優れた応答低减効果のあることを確認し ている。そして、1990 年には鉄骨造 3 階建て実建物に世界で初めて
* 鹿島小堀研究室 次長.工修

** 京都大学名誉教授, 鹿島最高技術顧問・工博

*** 鹿島小堀研究室 主管研究員・工修

**** 鹿島小堀研究室 研究員・工修
Deputy Senior Manager, Kobori Research Complex, Kajima Corp., M. Eng. Prof. Emeritus of Kyoto Univ., Chief Executive Adviser, Kajima Corp., Dr. Eng. Principal Research Engineer, Kobori Research Complex, Kajima Corp., M. Eng. Research Engineer, Kobori Research Complex, Kajima Corp., M. Eng. 
本システムを適用 ${ }^{11)}$ し、建物の強制振動実験そして竣工後の地震観 測を通してシステムが所期の性能を有していることを検証している。

装置はその減衰係数を変えることで振動系の剛性と減衰定数をあ わせて変えられるため ${ }^{177}$ 、適当な減衰係数を設定することにより、 可変剛性による非共振制御ができる上に、選択剛性タイプにある一 定の減衰性能を付与できる特性を有している。従って、実用上はこ の特性を有効に利用でき、また、本システムの有効性を評価するに 当たっては、この点について実際の建物を対象として、システムの ハード、ソフトを含めて実現し得る現実的な諸元をもとに定量的に 把握することが課題の一つとなっていた。そこで、ここではその基 礎的な 1 ステップとして、このような本システムの特性を、限られ た例とはなるが一般的な高層建物を対象として、それぞれ特徽を持 ついくつかの地震動を設定し、これを入力した場合の数值解析を通 して把握した。また、今後の本システムの開発に必要な資料を得る こととした。

高層建物を対象とした構造制御に関しては、これまで主に強風に

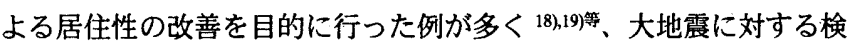
討は限られている 20)等。また、可変剛性制御によるものについては、 これまでいくつかの数值解析による検討があるが、そこでは可変判 性幅を可能な限り広くとるため、選択剛性タイプの保有する减衰性 能については期待せず、又、その影響については特に考慮していな かったり 21,22)、可変剛性による非共振制御効果の定量的な把握に検 討の余地が残されていた 23)。そこで、本報告では装置による減衰付 加を計画的に図り、選択可能な各剛性夕イプの 1 次減衰定数をほほ 揃えた設定をした上で可変剛性制御を行い、制御結果と各剛性夕イ プの応答、また本システムを設置しなかった場合とを比較し、これ をもとに制御並びに本システムの特性を建物の応答のみならずエネ ルギ入力の観点から定量的に把握し、大地震に対して本システムが 有効なものとなり得ることを示した。

\section{2. 可変剛性制震システムの概要}

(1) システム構成

本システムは図 1 に示すように油封式可変剛性装置、制御コン ピュータ、建物への入力地震動を計測するセンサからなる。建物の 剛性を可変する可変剛性機構は、通常はブレースなどの構造要素と 装置とを直列に接合して構成され、装置のロック、アンロックによ りブレースの接合状態を切り換え、これにより建物層㟠性を可変す る。

装置は図 2 に示すように油を内封した両ロッド型シリンダである。 左右の油圧室を䡔ぐ流路の途中にあり、数十ワットの電力で稼衝す る弁の開閉のみで装置両端の接合状態を切り換える機構となってい る。弁の開閉時それぞれの弁開度、すなわち減衰係数の設定により、 振動系の剛性並びに減衰定数が可変となる、バネと Maxwell モデル とが並列したモデルの特性を持つことが確認されている ${ }^{17 。}$

\section{（2）制御方法}

制御方法は、本システムにおいてこれまで採用してきた図 3 に示 すフィードフォワード制御である。入力地震動のみの情報をもとに、 以下に示すような簡便な算定式に基づいて棡性選択する実用的な制 御方法である。構造物の選択可能な各剛性タイプの応答を制御コン ピュータによりリアルタイムに計算し、次に示すような手順により
選択すべき剛性タイプを決定する ${ }^{24)}$ 。

まず、(1)式で定義される評価値を、着目する評価項目に相当する 応答量に対して制御時間間隔毎（ここでは $10 \mathrm{msec}$. 每）に計算する。 時刻 $t$ における剛性タイプ $i$ の評価項目 $k$ に関する評価値 $E_{i, k}(t)$ は、

$$
E_{i, k}(t)=\sqrt{\frac{\sum_{i, k=1}^{N_{i l, k}}\left(R_{i, k}\left(t-\Delta t \times N_{i, k}+\Delta t\right)\right)^{2}}{N_{i l, k}}}
$$

ここで、 $R_{i, k}(t)$ は時刻 $t$ での剛性タイプ $i$ の評価項目 $k$ に 関する応答值、 $t_{i, k}$ は剛性タイプ $i$ の評価項目 $k$ を評価する 際に考慮する周期、 $\Delta t$ は制御時間間隔、 $N_{i l, k}=t_{i, k} / 2 \Delta t$ は 㓮性タイプ $i$ の評価項目 $k$ を評価する際に考慮する周期の 半周期分の時間内の応答值のサンプリング個数である。

選択すべき剛性タイプは、(1)式をもとに(2)式で定義される剛性選 択用判定値が最小值を与えるものである。時刻 $t$ における剛性タイ プ $i$ の㓮性選択用判定值 $J_{i}(t)$ は、

$$
\begin{aligned}
& J_{i}(t)= \sum_{k}\left[C_{1, k}^{\prime} \frac{E_{i, k}(t)}{\max _{k}\left(\max _{i}\left(E_{i, k}(t)\right)\right)}+\right. \\
&\left.C^{\prime}{ }_{2, k} \frac{E_{i, k}\left(t-t^{\prime}\right) \times \max _{i}\left(E_{i, k}(t)\right)}{\max _{i}\left(E_{i, k}\left(t-t^{\prime}\right)\right) \times \max _{k}\left(E_{i, k}(t)\right)}\right]
\end{aligned}
$$

ここで、 $C^{\prime}{ }_{1, k}, C^{\prime}{ }_{2, k}$ は評価項目 $k$ に関する評価係数、 $t^{\prime}$ は 評価値の増減傾向を見るための微小時間である。

(1)、(2)式に基づき図 1 に示すようなシステムを用いて、実際に可 変剛性制御が実行可能であるという基本的確認は、本システムの縮

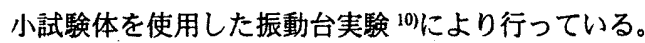

なお、本手法を採用したこれまでの検討結果から、地震動の卓越 周期の経時変化が比較的明瞭な地震の場合には、剛性切り換え指令 や制御効果は評価項目の設定、その組み合わせには比較的左右され ないという結果 ${ }^{24)}$ が得られているため、ここでは評価項目として建 物頂部変位を採用した。
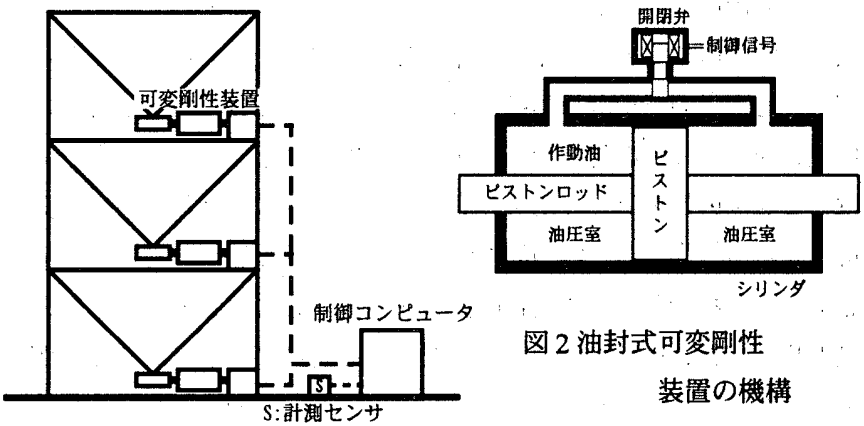

図 2 油封式可変剛性 装置の機構

図 1 可変剛性制震システムの構成

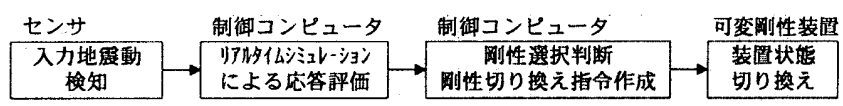

図 3 制御フロー 


\section{3. 検討対象及び解析条件}

\section{(1) 対象建物}

検討の対象とした建物は図 4(a),(b)に示すような一般的な 25 階建て 鉄骨フレーム構造を例として採用した。柱・梁フレームはベースシ ヤ一係数 0.07 で慣用的な耐震設計されたものである。以下、これを 原設計モデル（以下、原設計）と呼ぶ。このフレームの短辺方向を 検討対象とし、図に示すように可変剛性機構を付加的に設置した。

\section{（2）振動解析モデル}

フレーム部の振動解析モデルは、建物各階の質量を床位置に集中 させ、 1 本の等価な曲げ剪断棒に置換した多質点型振動解析モデル を用いた。曲げ変形に対しては弾性を、剪断変形に対しては、フ レームが塑性化した場合を考慮して 3 折れ線の Non-Degrading 型の復 元力特性を仮定した。ここで、第 1 折れ点は該当階上下梁の初降伏 点とし塑性率はこれを基準に評価した。フレームの減衰は内部粘性 減衰を仮定し 1 次周期に対して $2 \%$ とした。可変剛性機構は図 4(c),(d)に示すように、ブレースと装置剛性を評価したバネ要素と、 装置の可変ダッシュポット要素とを直列に配した Maxwell モデルと した。ただし、装置はフレーム層間の眑断変形にのみ効くよう剛棒 要素を用いてモデル化している。振動解析モデルの主要な諸元を示 すと、階高 $4.0 \mathrm{~m}$ の標準階の重量は $8.7 \times 10^{3} \mathrm{kN}(24$ 階 $) \sim 8.9 \times 10^{3} \mathrm{kN}$ （4 階）、フレーム剛性としての等価剪断断面積は $4.4 \sim 6.3 \times 10^{2} \mathrm{~cm}^{2}$ 、 等価断面 2 次モーメントは $1.2 \sim 2.7 \times 10^{6} \mathrm{~cm}^{4}$ であり、この間の階は それぞれほぼ比例的に変化している。なお、ブレースはここでは弾 性を仮定し、各層の全剪断剛性に対するブレースの剛性比は各首ほ ぼ 0.5 となっている。

(3) 可変剛性夕イプ

制御に用いる剛性タイプは、表 1 に示す 3 タイプとした。建物を 上層部、中層部、そして下層部の 3 ブロックに分け、それぞれの装 置の接続状態を表に示すように設定した。剛性切り換えは Maxwell モデルのダッシュポット要素の減衰倸数を切り換えて行う。ここで は各剛性タイプのダッシュポット要素の減衰係数を表 1 に示すよう に決めた。各剛性タイプの減衰系固有值を求めるため複素固有值解 析 ${ }^{17)}$ をした結果を表 2 に示す。各剛性タイプの 1 次モード減衰定数 はほぼ 10\%となっている。なお、1 次モード减衰定数 $10 \%$ という值 は、あらかじめ設定した複数の減衰係数に対して複素固有値解析を 行い、タイプ 1 と 3 の減衰系 1 次周期が可変剛性制御の効果を高め る観点からできるだけ離れた值を持ち、かつその時の 1 次減衰定数 ができるだけ高く、両者ともほぼ同一の値となるよう設定したもの である。タイプ 2 はこれと同様の 1 次減衰定数を持ち、減哀系 1 次 周期が両タイプの中間値となるよう装置の配置を決定した。これら をもとに制御を行うモデルを可変剛性モデ（以下、制御時）と呼 ぶ。

以下の応答結果の比較検討においては、制御を行わない各剛性夕 イプに比ベた制御時を、ここでは可変剛性制御による応答低減効果 (以下、制御効果) と呼ぶ。従って、原設計に比べた制御時は、制 御効果に装置の減衰付加性能による効果を合わせた本システム設置 による応答低减勃果を示す。なお、装置の減衰付加性能のみによる 応答低減効果は原設計に比べたタイプ 1に見ることができる。

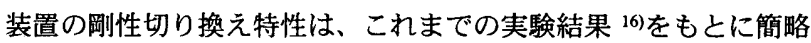
化して表し図 5 に示すよう仮定した。なお、剛性切り換え指令は各
装置に対して同時に与えられるとした。

\section{(4) 入力地震波}

本システムの基本的な特性を評価することを主目的に、ここでは 過去の地震観測記録の中からそれぞれ特徵ある幾つかの地震動波形 を用いた。採用した入力地震動波形は、HACHINOHE 1968 (NS),
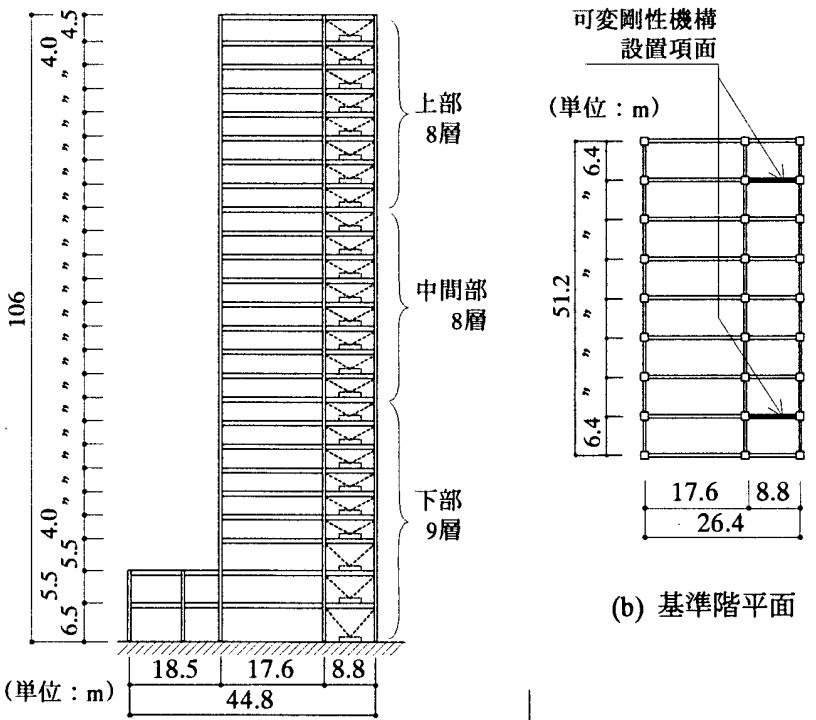

(b) 基淮階平面

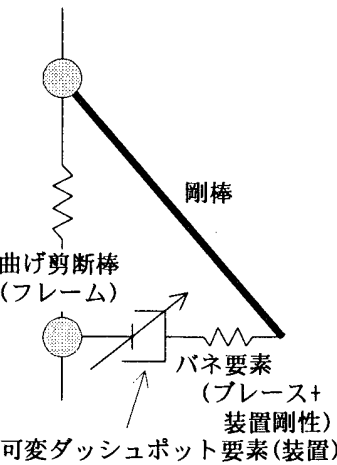

(c) 可変剛性機構設置部分 $\quad$ (d) 可変剛性機構モデル

図 4 検討対象建物と解析モデル

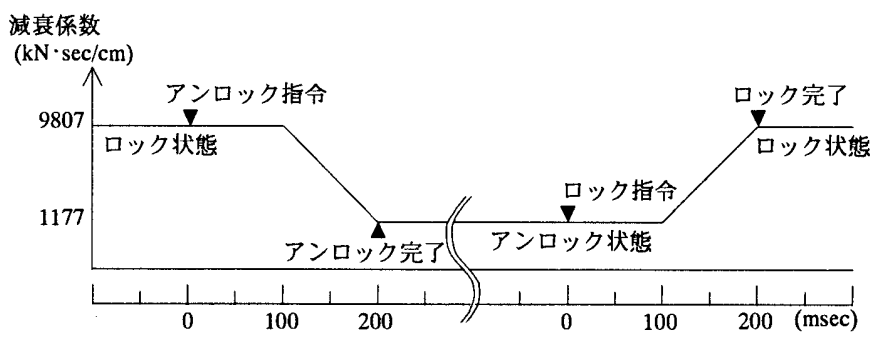

図 5 可変剛性装置隇衰係数切り換えタイムチャート

表 1 可変剛性タイプ

\begin{tabular}{|c|c|c|c|c|}
\hline 位置建物用性 & タイプ1 & タイプ 2 & タイプ 3 & 備考 \\
\hline 上部 8 層 & Pンロック & アンロ多 & ロック & ダッシュポ ットの減衰係数 \\
\hline 中間部 8 層 & P吅少 & アンロック & ロック & 口紧時 $: 9807 \mathrm{kNsec} / \mathrm{cm}$ \\
\hline 下部 9層 & アンロク & ロック & ロック & アンロ多時: $1177 \mathrm{kNsec} / \mathrm{cm}$ \\
\hline
\end{tabular}

表 2 複素固有値解析結果

\begin{tabular}{|c|l||c|c|c|c|}
\hline \multicolumn{2}{|c|}{ 次数 } & タイプ 1 & タイプ 2 & タイプ 3 & 原設計 \\
\hline \hline \multirow{2}{*}{ 1 次 } & $\mathrm{T}(\mathrm{sec})$ & 3.52 & 3.18 & 2.80 & 3.57 \\
\cline { 2 - 6 } & $\mathrm{h}(\%)$ & 10.0 & 10.9 & 10.4 & 2.0 \\
\hline \multirow{2}{*}{2 次 } & $\mathrm{T}(\mathrm{sec})$ & 1.06 & 0.95 & 0.88 & 1.21 \\
\cline { 2 - 6 } & $\mathrm{h}(\%)$ & 24.6 & 17.9 & 11.5 & 5.9 \\
\hline \multirow{2}{*}{3 次 } & $\mathrm{T}(\mathrm{sec})$ & 0.55 & 0.53 & 0.49 & 0.69 \\
\cline { 2 - 6 } & $\mathrm{h}(\%)$ & 28.1 & 24.8 & 17.0 & 10.4 \\
\hline
\end{tabular}


MEXICO-CDAO 1985 (NS), KOBE-JMA 1995 (NS), SAKAI 1995 (NS)の 計 4 波（以下、それぞれ HACHINOHE, MEXICO, KOBE, SAKAI) で ある。各地震波の最大振幅及び継続時間を表 3 に、応答スペクトル を図6にそれぞれ示す。

HACHINOHE は高層建物の構造設計に慣用的に用いられる地震波 のうち長周期成分を含む例で、最大速度は慣例のレベル 2 地震に相 当する $50 \mathrm{~cm} / \mathrm{sec}$ とした。MEXICO は長周期に比較的狭帯域の成分を 有する特徵的な地震波で、高層建物のような長周期構造物の応答に 大きな影響を与える可能性のあるものである。後者 2 波は、先の兵 庫県南部地震の際に神戸と堺で記録された地震波で、震源に極めて 近い.KOBE と、震源から約 $50 \mathrm{~km}$ 離れた大阪平野に位置する SAKAI である。SAKAI はいわゆる「あと摇れ」25)と呼ばれる大阪平野特有 の後続位相のやや長周期成分を含んだものである。なお、後者 3 波 の最大振幅はここでは観測記録のまま用いた。

\section{4. 解析結果}

（1）建物頂部応答変位に見る制御効果

可変剛性による制御効果並びにその特性の全体的傾向を見るため に、ここでは建物頂部変位に着目して結果を考察する。 a．時刻歴上に見る剛性切り換え指令と制御効果

図 7 から図 10 には各地震波について、(a)入力地震波の加速度時刻 歴、(b)ランニング変位応答スペクトル（减衰 $10 \%$ 、以下、ランニン グスペクトル）と可変剛性切り換え指令、(c)制御時並びに制御を行 わない各剛性タイプの建物頂部応答変位時刻歴をそれぞれ示す。こ こで、(c)は可変剛性制御の経過を把握する一つの方法として、建物 頂部の応答変位時刻歴（以下、変位時刻歴）について制御時と各剛 性タイプの応答とを比較して示したものである。また、参考までに 原設計の結果を併せて示した。なお、ここでは示さないが応答加速 度波形に剛性切り換えによる特別な影響は現れていない。

HACHINOHE では、ランニングスペクトルは 20 秒付近及び 30 秒

表 3 入力地震波諸元

\begin{tabular}{|l||c|c|c|}
\hline \multirow{2}{*}{\multicolumn{1}{|c|}{ 地震波名 }} & 最大速度 & 最大加速度 & 継続時間 \\
\cline { 2 - 4 } & $(\mathrm{cm} / \mathrm{sec})$ & $\left(\mathrm{cm} / \mathrm{sec}^{2}\right)$ & $(\mathrm{sec})$ \\
\hline \hline HACHINOHE 1968(NS) & 50.0 & 338.1 & 120.0 \\
\hline MEXICO-CDAO 1985 (NS) & 35.0 & 69.0 & 180.0 \\
\hline KOBE-JMA 1995 (NS) & 91.0 & 818.0 & 60.0 \\
\hline SAKAI 1995 (NS) & 15.9 & 148.6 & 100.0 \\
\hline
\end{tabular}

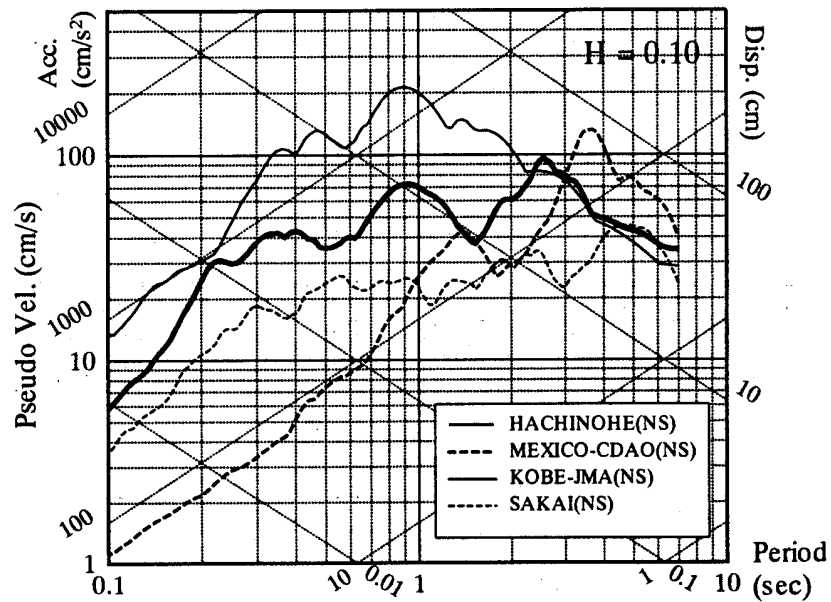

図 6 入力地震波の応答スペクトル
から 40 秒にかけて、周期 2 秒から 4 秒以上に渡る比較的広带域の 2 つのピーク帯が見られる。制御はこの間、ピークのより小さいタイ プ 1 を選択している。これ以降はタイプ 1 を主とし、タイプ 2 ある いは 3 を部分的に選択している。変位時刻歴では、ランニングスペ クトルで指摘したピーク付近で各タイプとも応答が増大しているが、 制御によりタイプ1が選択され応答をより小さくしている。

MEXICO では、ランニングスペクトルは 60 秒以降で周期 3 秒から 4 秒を越えるところに比較的狭帯域の幾つかの明瞭なスペクトル ピークのある特徵的な様相を示し、制御はこれを避けるよう地震継 続時間中、主にタイプ 3 を選択している。変位時刻歴では各タイプ は 1 次減衰定数ではほぼ 10\%程度を有するにもかかわらず、応答に 大きな差が生じており、なかでも夕イプ 1 では 80 秒以降で明暸な共 振状態を示し 3 㴊性タイプのうち最も大きく応答している。制御に より主にタイプ 3 が選択され、地震動に対して非共振化が図られほ ぼ最小の応答となり、顕著な制御効果が見られる。

KOBE では、ランニングスペクトルには、10 秒付近に集中して周 期 1 秒から 4 秒以上の広い周期篂囲に渡り際だったピ一ク帯が見ら れ、制御はタイプ 1 を選定し、このピークを越えた直後の 12 秒付近 でタイプ 3 に切り換えている。変位時刻歴では各剛性タイプとも比 較的似た傾向を示し、地震開始直後のパルス的な特徵ある応答を示 している。最大值はこの付近で生じ、制御によりタイプ 1 が選択さ れ 3 剛性夕イプの中ではほほ最小の応答を与えている。制御時のこ の最大值を示す付近の変位時刻歴からは、応答において 2 次以上の 高次モードが卓越していることが推測される。

SAKAI では、ランニングスペクトルは地震前半の 15 秒付近から 35 秒付近にかけて周期 2 秒から 3 秒の間にスペクトルの比較的卓越 した箇所が、また、地震後半の 50 秒以降には周期 3 秒以上の比較的 狭帯域の 2、3 の明膫なピークが見られる。制御は地震前半のスペク トルの卓越した箇所では、これを避けるように主にタイプ 1 を選択 し、地震後半では周期 3 秒以上のピークをかわすように主にタイプ 3 を選択し、地震動の変化する特性に応じた剛性切り換えが実現さ れている。変位時刻歴では、地震前半ではタイプ 3 の応答が比較的 大きく、地震後半ではタイプ 1 の応答が卓越する傾向はランニング スペクトルと対応している。制御時の塘答は、地震動の特性に合わ せた剈性選択により、全継続時間に渡って小さな応答を実現し影著 な制御効果が認められる。

b. 店答最大変位に見る制御効果

前項に示した建物頂部応答変位の最大値に着目して整理した結果 を図 11 に示す。なお、各棒グラフの横の括弧内には最大值の起生時 刻を記す。制御時と各剛性タイプを比較し、最大值における制御効 果を見ると、採用した 4 地震波全てについて制御時は各タイプの内 のほほ最小を実現していることがわかる。特に MEXICO 及びSAKAI では地震に対する共振の程度により各タイプの差が大きく、前節で 見たように顕著な制御効果が認められる。このように応答に差が生 ずるということは、これらの地震に対し、仮に各タイプそれぞれの 固定した周期特性を持つ構造があれば、応答は図に示すように大き く異なり、それぞれの構造は安全上大きな差を生ずることとなる。 本システムは制御により共振を避けることによって、このような臆 念を払拭する際だった特徵を有している。なお、MEXICO では制御 時は最小値を与えるタイプ 3 より僅かながら大きい。制御時の最大 


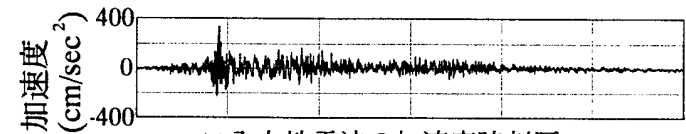

(a)入力地震波の加速度時刻歴

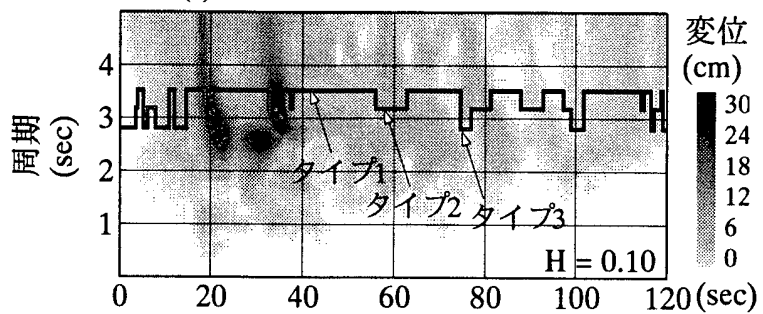

(b)ランニング変位応答スペクトルと剛性切り換え

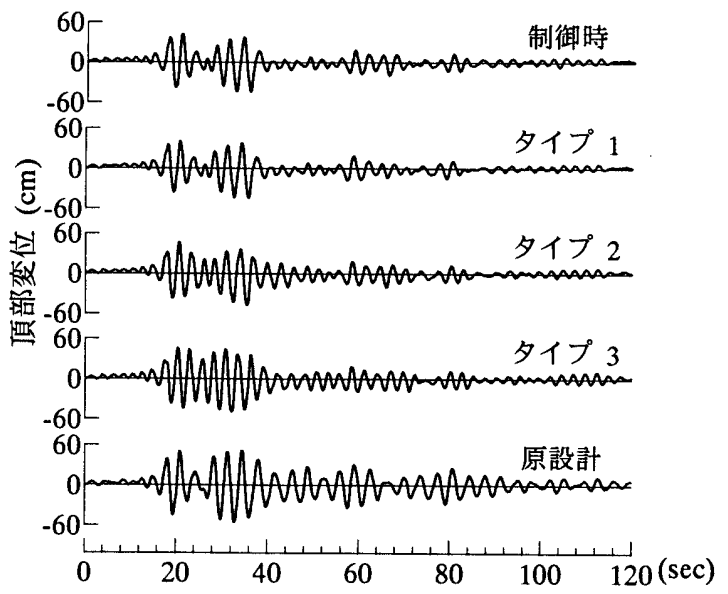

(c)建物頂部応答変位時刻歴

図 7 HACHINOHE 入力による解析結果

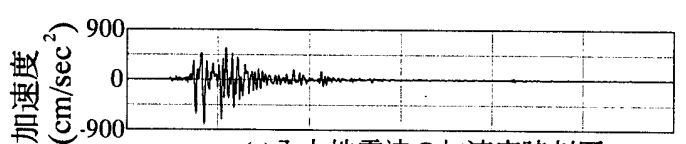

(a)入力地震波の加速度時刻歷

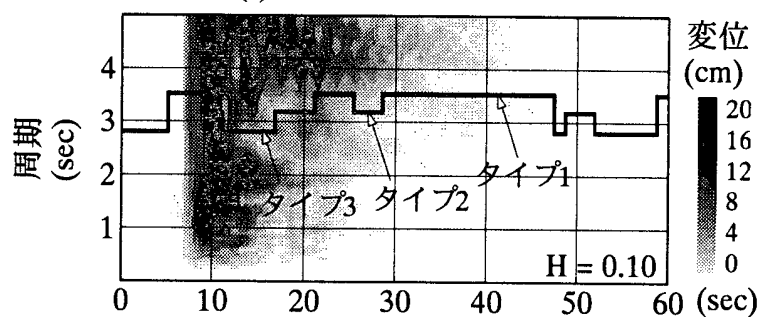

(b)ランニング変位応答スペクトルと剛性切り換え

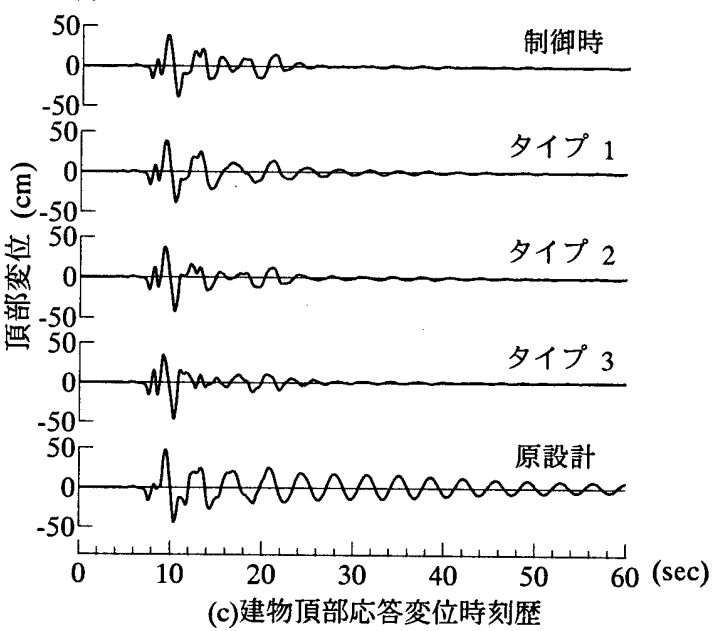

図 9 KOBE-JMA入力による解析結果

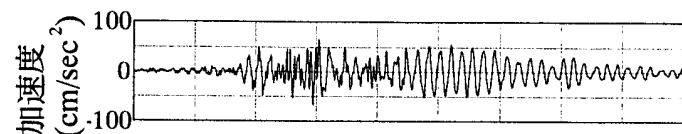

(a)入力地震波の加速度時刻歴

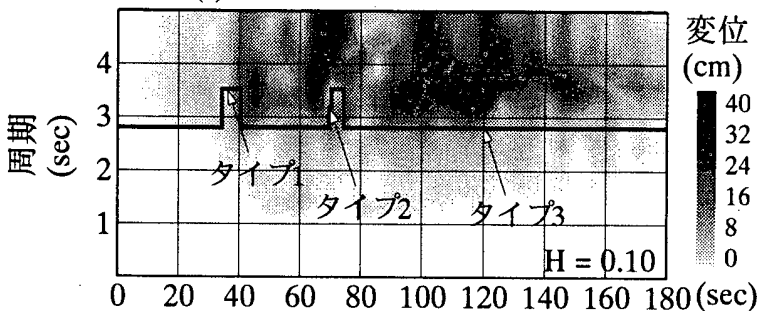

(b)ランニング変位応答スペクトルと剛性切り換え

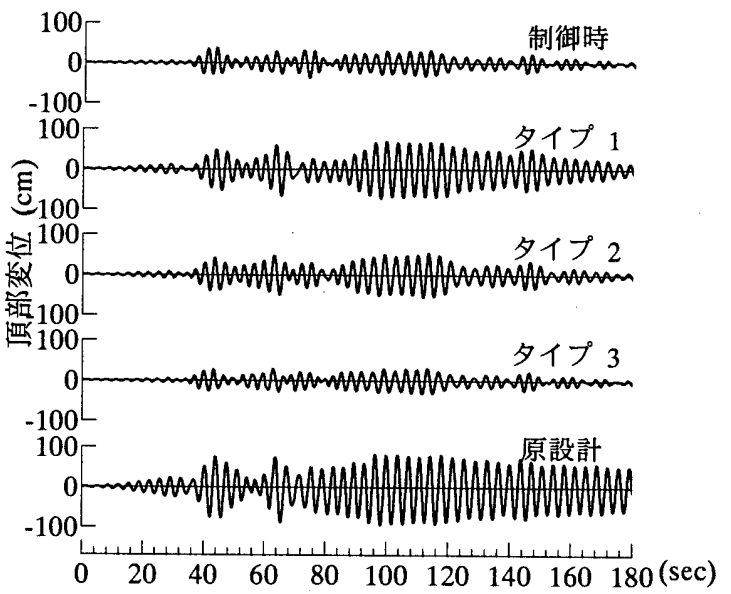

(c)建物頂部応答変位時刻歴

図 8 MEXICO 入力による解析結果

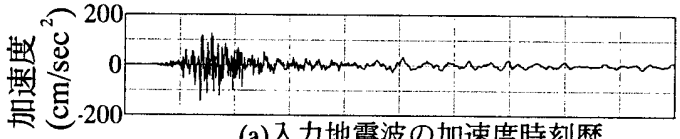

(a)入力地震波の加速度時刻歴

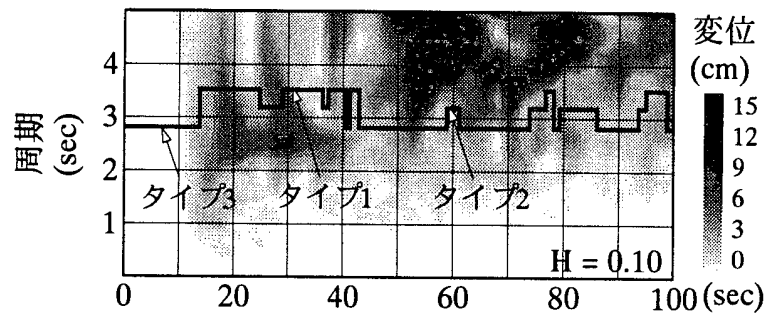

(b)ランニング変位応答スペクトルと剛性切り換え

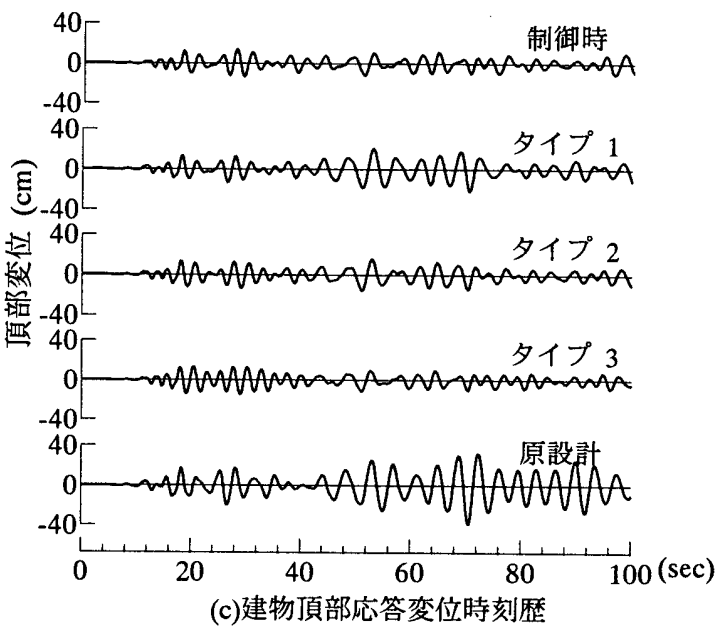

図 10 SAKAI 入力による解析結果 
值は 43.2 秒に起生しているが、図 8(b)の剛性切り換え経過から、制 御開始後タイプ 3 からタイプ 1 に切り換え、その後の 40 秒付近での タイプ 3 人切り換えが遅かったことが原因と推定され、採用した剛 性選択方法に改良の余地のあることが示唆される。

HACHINOHE 及び KOBE では各剛性タイプの応答值の差は比較的 小さく、制御勏果は先の 2 地震波に比べて小さい。これは前節でも 見たように、これらの地震による各夕イプの応答最大値が、比較的 広帯域の周期特性を持つスペクトルのピーク帯においてほぼ同じ時 間帯に起生することに起因しているものと考えられる。しかしなが ら、本システムはそもそも装置の隇衰係数の設定により、各剛性夕 イプとも 1 次減衰定数でほほ $10 \%$ の減衰性能が付加されており、こ れによる効果の一例は原設計とタイプ1の比較において見い出せる ものである。従って、HACHINOHE や KOBE のような地霞に対して も、制御による効果は少ないものの、本システムは装置による隇衰 付加性能により安定した応答低减効果を有している。

（2）制御時の応答最大值分布

制御の結果得られた建物の応答レベルを見ることにより本システ ムの効果を把握するため、ここでは応答最大值分布に着目する。

図 12 には制御時の各地震波についてフレーム剪断力及び層間変形角 の応答最大值分布を示す。なお、壿断力の図にはフレームの弾性限 に対する応答の程度を計る目安として弾性限剪断力を、また、参考 までに原設計の結果を併記した。

SAKAIは入力レベルが小さく、他の 3 地震波に比べ応答レベルは 小さいが、ここで採用した条件下においては、4地震波に対して制 御時の剪断力はほほ弾性限以下に、また、首間変形角は 0.005 （1/200）程度以下となっている。SAKAIを除く 3 地震波はいわゆる 大地震に相当すると考えられ、これらの地震波に対してこの程度の
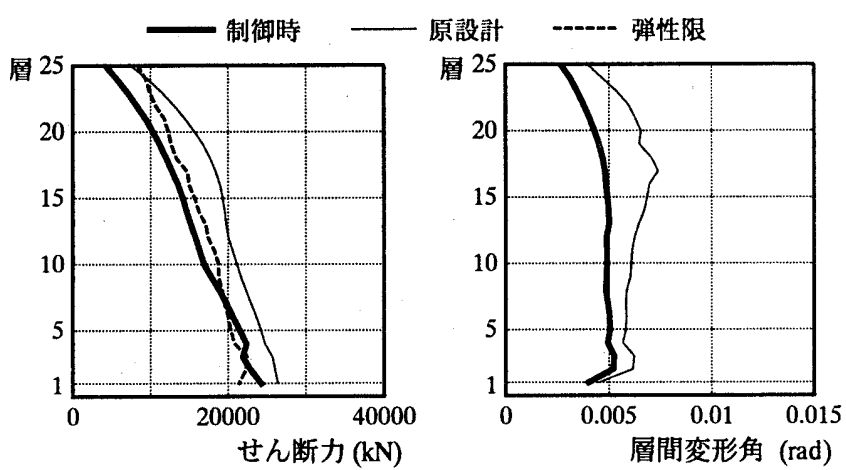

(a) HACHINOHE
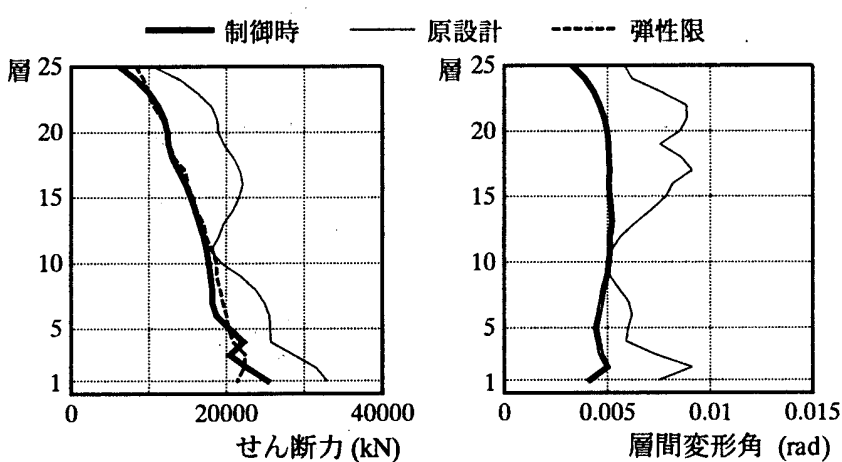

(c) KOBE-JMA
応答レベルにおさまるという結果は、構造安全上も、また建築や設 備の変形による機能損傷を防止する上にも、本システムが優れた効 果のあることを示す例といえる。なお、通常の耐震設計されたフ レームに相当する原設計では弾性限を越え、最大塑性率はKOBEで 2.22 (22階)、最大首間変形角はMEXICO で0.012 (1/87) ( 6階) となって いる。

MEXICO 及びSAKAI においては愬断力、層間変形角とも制御時と 原設計の差が他の 2 地震波に比べて大きく、前節までに見たように、 制御効果に装置による減衰付加効果を合わせた本システムの効果を

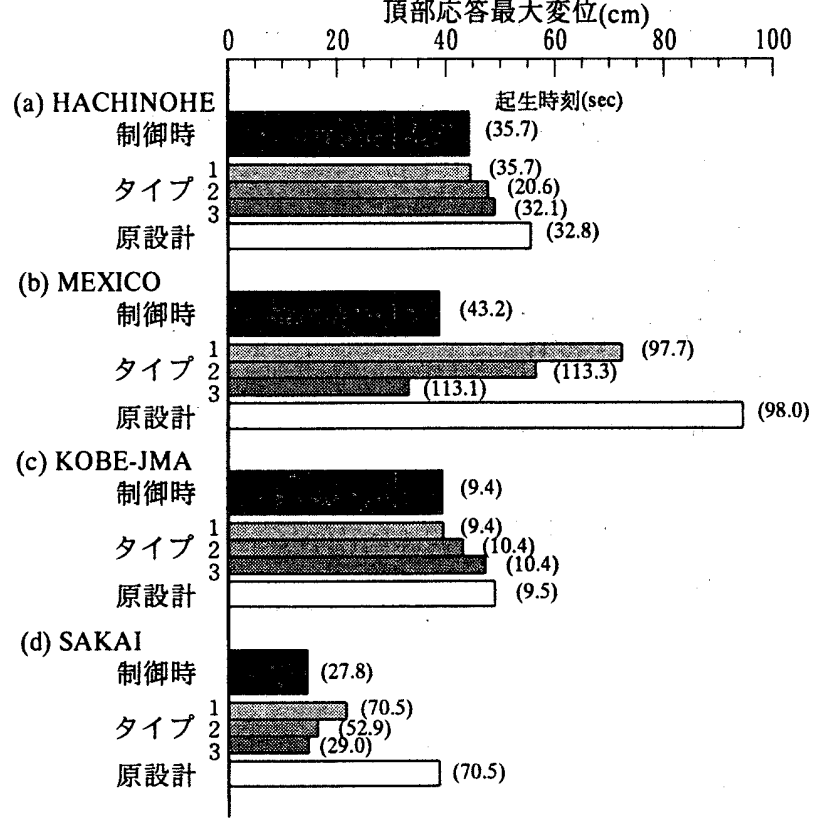

図 11 建物頂部応答最大変位の各地震波による比較
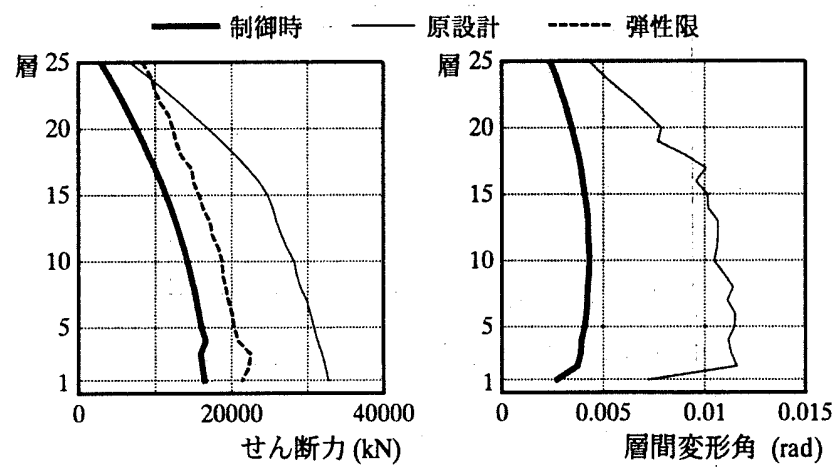

(b) MEXICO
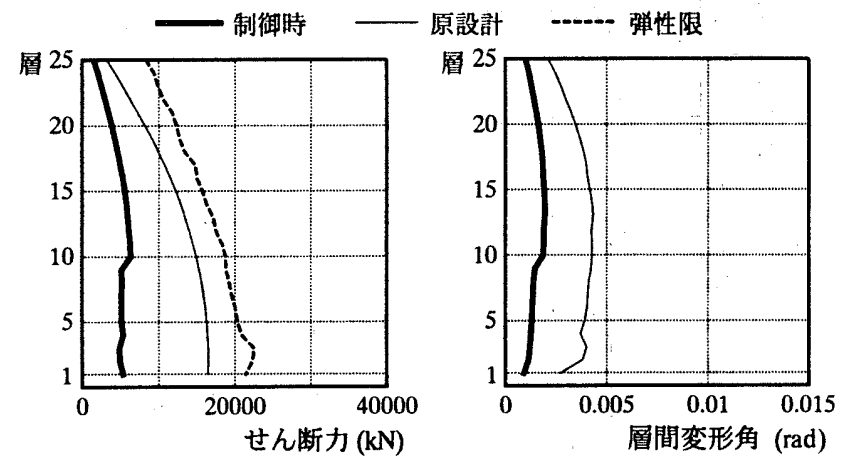

(d) SAKAl

図 12 応答最大值分布の各地震波による比較 
応答最大值分布の上で確認できる。

なお、制御時の装置発生減衰力は一般にロック状態に大きくなる 傾向にある。本例の場合では、制御時にロック状態（タイプ 3）を 主に選択する MEXICO において装置の最大減衰力は約 $1.62 \times 10^{4} \mathrm{kN}$ （3 階）となっている。通常はこれら減衰力に見合った装置を首毎 に複数台設置することになる。

（3）エネルギ入力に見る可変剛性制御の特性

可変剛性制御の特性をエネルギ入力の観点から考察するため、工 ネルギの釣り合い式(3)に基づき、各項のエネルギ成分を計算した。

$$
\begin{aligned}
\int_{0} m_{i} \ddot{X}_{i} \dot{X}_{i} d t+ & \int_{0}^{t} c\left(\dot{X}_{i}\right) \dot{X}_{i} d t+\int_{0} D\left(\dot{X}_{i}\right) \dot{X}_{i} d t \\
& +\int_{0}^{d} Q\left(X_{i}\right) \dot{X}_{i} d t=-\int_{0}^{t} m_{i} \ddot{Y}_{0} \dot{X}_{i} d t
\end{aligned}
$$

ここで、 $\ddot{Y}_{0}$ は地動加速度、 $X_{i}$ は各階水平変位、 $c\left(\dot{X}_{i}\right)$ は内部粘 性減衰力、 $D\left(\dot{X}_{i}\right)$ は装置減衰力. $Q\left(X_{i}\right)$ は復元力である。よって、 (3)式の左辺は順に、運動エネルギ、内部粘性減衰エネルギ、装置に よる減衰エネルギ、履歴減衰エネルギ、そして右辺は入力エネルギ を示す。

図 13 には、(3)式の右辺に相当する入力エネルギの時刻歷を各地震 波について、制御時と制御をしなかった各剛性タイプの結果を比較 して示す。 4 地震波とも、制御時は剛性タイプのうち最小のものに 近接して推移していることがわかる。特に、MEXICO においては、 タイプ 1 の 90 秒以降、共振による急激な入力エネルギの増加が見ら れるが、制御により主にタイプ 3 が選択されてこれを避け、入力エ ネルギを小さくしている。また、SAKAI では、タイプ 3 が地震前半 の 15 秒から 20 秒付近、及び 25 秒から 35 秒付近にかけて入力エネ ルギの増加が著しく、地震後半の 60 秒以降でタイプ 1 の増加が激し い。制御は地震前後半において入力エネルギの小さいところを採り、 地震終了時にはどの剛性タイプよりも小さな值となっており、可変 剛性制御の他の制震システムには見られない大きな特徵を示してい る。

図 14 には地震終了時の (3) 式左辺の第 2〜第 4 項に相当する各工 ネルギ成分を、各地震波について制御時、各剛性タイプを比較して

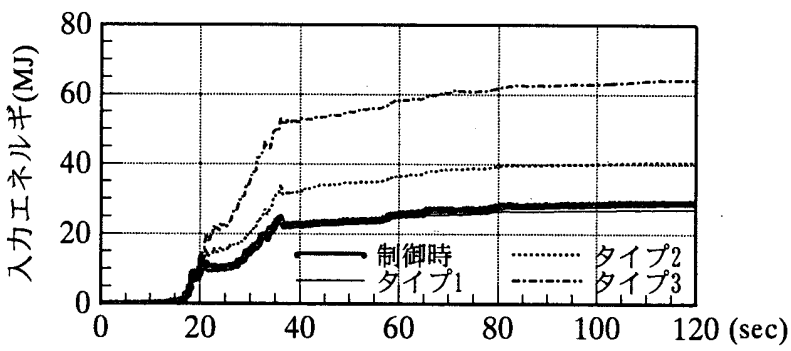

(a) HACHINOHE

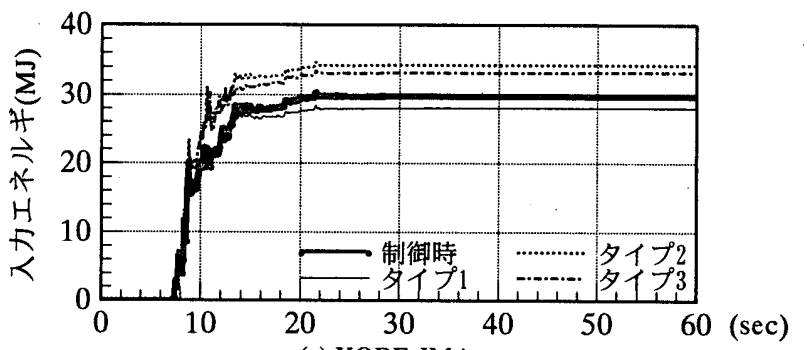

(c) KOBE-JMA
示す。ここで、横軸は制御時の入力エネルギを 1.0 として示す。な お、運動エネルギは地震終了時は他のエネルギ成分に比べ無視しう る值となっている。

3 剛性タイプの入力エネルギを比較すると、HACHINOHE では最 大のタイプ 3 と最小のタイプ 1 では 2 倍以上の、また MEXICO では 同様の差が 3 倍以上となっている。これらは共に 1 次減衰定数が 10\%程度あるにもかかわらずこれだけの差が生じたものであるが、 制御によりほぼ最小に近い結果が得られている。なお、入力エネル ギと応答最大変位の周期に依存して変化する傾向は一般に異なるた め、図 14 と図 11 との比較において見受けられるように各剛性夕イ プの大小関係の傾向は必ずしも一致しない。

ここで、装置により吸収される減衰エネルギを見ると、入力エネ ルギの大小と傾向をほぼ同様にしており、入力エネルギの低減が装 㯰の吸収する減衰エネルギを低減することがわかる。すなわち、可 変剛性制御は装置の吸収する減衰エネルギが小さくとも MEXICO や

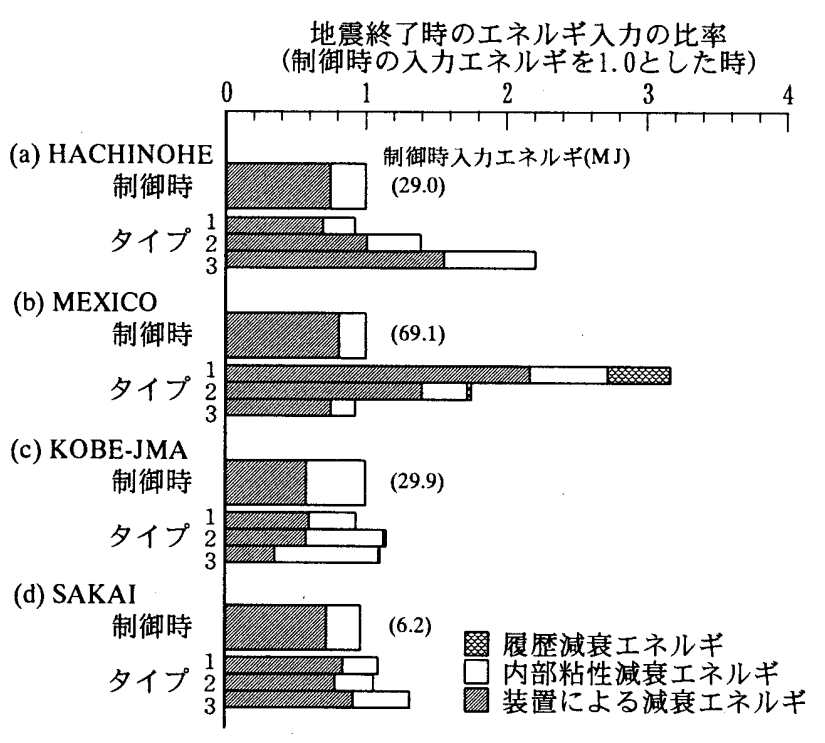

図 14 地震終了時のエネルギ入力の比率に関する 各地震波による比較

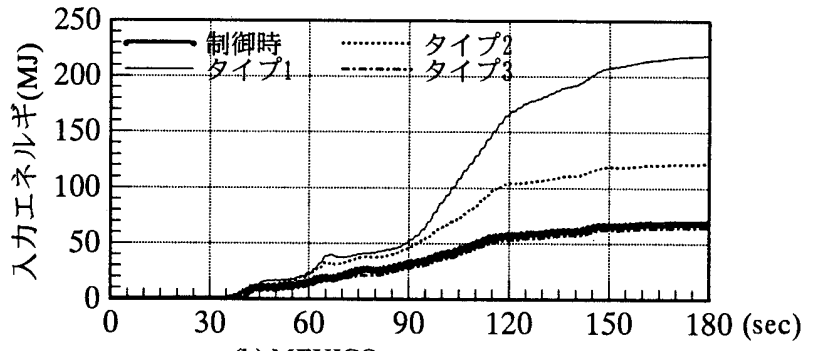

(b) MEXICO

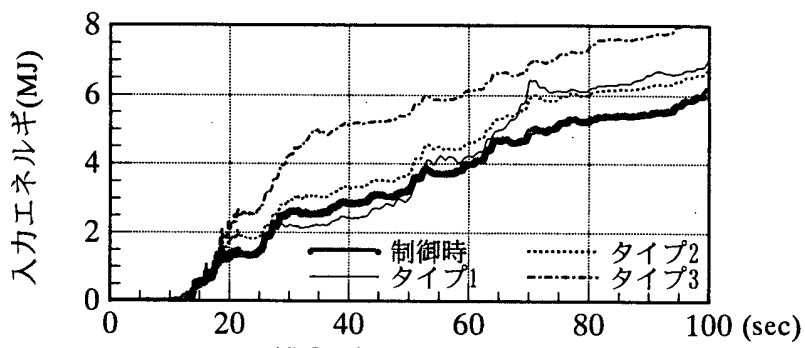

(d) SAKAI

図 13 入力エネルギ時刻歴の各地震波による比較 
SAKAl で見たような大きな応答低减効果が得られるという、エネル ギ吸収型の制震システムでは実現できない特徽を有している。なお、 KOBE においては、装置の減衰エネルギの入力エネルギに対する割 合が他の 3 地震波に比べ小さい。特に、固有周期の短いタイプ 3 に おいて顕著である。これは建物頂部応答変位時刻歷の節で見たよう に、応答に高次モードが卓越しておりエネルギ吸収にかかわる装置 の効きが低下したためと考えられる。

\section{5. 結論}

油封式可変剛性装置を使い非共振型の制御を行う大地震対応の可 変剛性制震システムについて、ここでは一般的な高層建物を対象と して、システムを含めて現実的な諸元に基づき、特徵的な 4 地震波 を入力した数值解析を通してその特性を定量的に把握した。この際、 選択可能な各剛性タイプの 1 次减衰定数をそれぞれほほ $10 \% に$ 設定 し、装置の持つ減衰付加性能に加えて可変剛性による制御効果を評 価した。限られた例ではあるが、本研究から得られた知見は以下の 通りである。

（1）採用した可変剛性制御により、本研究で取り上げた 4 地震波 に対して、建物の頂部応答変位は時刻歴上及び最大值において制御 をしなかった各選択剛性タイプの内ほほ最小となった。特に、 MEXICO や SAKAI のような比較的狭帯域の周期成分を有する地震波 に対しては、各タイプの応答は共振の程度により大きな差が生じる が、制御により非共振化が図られ顕著な効果が得られた。これは、 建物の安全を最も妿かす共振応答を励起する周期成分が地震動中に 多く含まれるほど制御効果が際だつという本システムの特徵を示す。

(2) 一方、HACHINOHE や KOBE のように、ある時間帯に比較的 広帯域の周期成分を有する地震波に対しては、制御効果は前 2 地震 波に比べ顕著ではない。しかしながら、本システムは装置の保有す る減衰付加性能により、これらの地震波に対しても安定した応答低 減効果を有している。

（3）（1）、（2）より、本システムは可変剛性による制御効果に 加え、装置による減衰付加性能により、多様な特性を持つ大地震に 対して有効な制震システムとなり得る。

（4）制御時の入力エネルギは制御しなかった各剛性タイプの内ほ ぼ最小となった。特に、SAKAI のように地震の継続時間中に卓越周 期成分が明瞭に変化するような場合においては、地震終了時の入力 エネルギは制御によってどのタイプよりも小さい結果を得た。また、 制御により装置の吸収する減衰エネルギも同時に低減できる傾向が あるため、可変剛性制御はより小さな减衰エネルギ吸収能力を持つ 装置で MEXICO や SAKAI で見られたような大きな応答低减効果が 得られる。これらは他の制震システムには見られない本システムの 特徽である。

（5）地震動の特性は、もとより地震毎に異なる不確定なものであ り、また建物の周期特性もそれぞれ異なるものではあるが、ここで 確認された本システムの特性は、高層建物や免震構造物などの長周 期構造物のやや長周期地震動 20)に対して燱念される設計上の課題に 対し、本システムが有力な解決策の一つを与え得ることを示唆して いる。

なお、ここでは本システムの特性を、システムも含めて現実的な 諸元をもとに定量的に把握する事を目的としたため、対象建物を高
首建物に限定したが、周期特性の異なる他の建物や、他の特性を持 つ地震波についても今後検討する予定である。

\section{参孝文献}

1) Kobori, T. : Mission and Perspective towards Future Structural Control Research, Proceedings of the Second World Conference on Structural Control, Vol.1, pp.25-34, 1998.6

2) Housner, G.W. et al. : Structural Control - Past, Present, and Future, Special Issue of Journal of Engineering Mechanics, Vol.123, No.9, 1997

3）西谷章 : アクティブ制震技術、建築雑誌 Vol.114 No.1439,pp.36-37, 1999.6

4）日本建榮学会：特集一免震、建䓩雑誌、Vol.112, No.1414, 1997.11

5) 小珮鐸二：耐震構造の新しい展開、内藤多仲生誕 100 年記念文集, 1986.5

6) Kobori, T. : Future Direction on Research and Development of Seismic-ResponseControlled Structure, Proceedings of the First World Conference on Structural Control, Vol.1, pp.Panel-19-31, 1994.8

7) Kamagata, S. et al. : Autonomous Adaptive Control of Active Variable Stiffness System for Seismic Ground Motion, Proceedings of the First World Conference on Structural Control, Vol.2, pp.TA4-33, 1994.8

8）池田芳桔、他：瞬間最適化手法による1 自由度系構造物に対する可変岡 性型制御システム、日本建築学会構造系論文集、第 435 号、pp.51-59、 1992.5

9) Yamada, K. et al. : Control Algorithm for Estimating Future Response of Active Variable Stiffness Structure, Earthquake Engineering and Structural Dynamics, Vol.24, pp.1085-1099, 1995

10) 小䏱鐸二、他 : 多層構造物による可変剛性制震システムの振動台実験、第 8 回日本地震工学シンポジウム, pp.1923-1928,1990.12

11) Kobori, T. et al. : Seismic response controlled structure with active variable stiffness system, Earthquake Engineering and Structural Dynamics, Vol.22, pp.925- 941, 1993.11

12) Niwa, N. et al. : Application of Semi-active Damper System to an Actual Building, Proceedings of the Second World Conference on Structural Control, Vol.1, pp.815. 824, 1998.6

13) Kurino, H. et al. : Semi-active Structural Response Control by Optimizing the Forcedeformation Loop of Variable Damper, Proceedings of the Second World Conference on Structural Control, Vol.1, pp.407-416, 1998.6

14) Patten, W.N. : The I-35 Walnut Creek Bridge : An Intelligent Highway Bridge via Semi-active Structural Control, Proceedings of the Second World Conference on Structural Control, Vol.1, pp.427-436, 1998.6

15) Iwan, W.D. et al. : A Comparison of Control Algorithms for Active Interaction Control of Civil Structures, Proceedings of the Second World Conference on Structural Control, Vol.2, pp.1559-1567, 1998.6

16）小梮鐸二、他 : 可変剛性機構を有する実大鉄骨骨組の動的加力実験、檴造 工学論文集 Vol.37B, pp.317-328, 1991.3

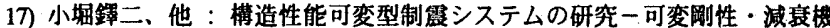
構の基本特性と振動台による基礎実驗一、槽造工学論文集、Vol.37B, pp.183-191, 1991.3

18) Kondo, A. et al. : Application of Active-Passive Composite Tuned Mass Damper, Proceedings of the Second World Conference on Structural Control, Vol.3, pp.22792287, 1998.6

19) Higasino, M. et al. : Application of Active Mass Damper (AMD) System, and Earthquake and Wind Observation Results, Proceedings of the Second World Conference on Structural Control, Vol.1, pp.785-794, 1998.6

20) Kurata, N. et al. : Active Variable Damping System in Large Earthquakes, Proceedings of the third International Conferense on Motion and Vibration Control, Vol.3, pp.285-290, 1996.9

21）那須正、他：可変剧性 (AVS) 制震システムの高層建物への適用研究、構造 工学諭文集 Vol.41B, pp33-38, 1995.3

22) 那須正、他 : 兵庫県南部地震・大阪平野観测記録を用いた AVS 制震シス テムの高層建物適用シミュレーション解析、構造工学論文集 Vol.42B, pp.1$8,1996.3$

23) T.Nasu et al. : Analytical Study on a High-rise Building with the Active Variable Stiffness System, Proceedings of the Second World Conference on Structural Control, Vol.1, pp.805-814, 1998.6

24）那須正、他：可変用性（AVS）制震システムの制御方法とその有効性に関 する研究、棈造工学論文集、Vol.40B、pp.133-145、1994.3

25) 鳥海勲 : 大阪平野のあとゆれについて、第 24 回地盤霞動シンポジウム, pp.65-70, 1996.10

26）例えば、釜江克宏、入倉孝次郎：1946 年南海地震（ $\mathrm{M}_{\mathrm{w}}=8.1 ）$ 時の震源近傍 及び周辺地域における強震動評価、日本建築学会構造系論文集、第 455 号、 pp.61-71、1994.1 